\title{
KARAKTERISTIK PERMASALAHAN YANG DIHADAPI OLEH BADAN AKUNTABILITAS KEUANGAN NEGARA DPR RI DALAM MENGIMPLEMENTASIKAN KEBIJAKAN
}

\author{
A. Junaidi Auly ${ }^{1}$, Bahrullah Akbar ${ }^{2}$, Didik Suhardi ${ }^{3}$, Nirva Diana ${ }^{4}$ \\ ${ }_{1,2,3,4}$ Institut Pemerintahan Dalam Negeri (IPDN) \\ Email: junaidi.auly@gmail.com
}

\begin{abstract}
Abstrak
Penelitian ini mempelajari karakteristik permasalahan yang di hadapi oleh Badan Akuntabilitas Keuangan Negara DPR RI, dimana hal ini telah menjadi hambatan bagi BAKN dalam mengimplementasikan kebijakan-kebijakan terkait akuntabilitas keuangan negara. Metode penelitian dalam penelitian ini menggunakan pendekatan kualitatif dengan menggunakan metode deskriptif yang menggambarkan karakteristik permasalahan dalam implementasi kebijakan. Adapun teori yang digunakan adalah teori implementasi yang dikemukakan oleh Mazmanian dan Sabatier. Temuan penelitian menunjukan bahwa dilihat dari karaktersitik masalah diketahui bahwa implementasi kebijakan MD3 oleh BAKN masih memiliki kesukaran terknis termasuk aturan-aturan termasuk tugas BAKN hanya sebagai penelaahan. Selain itu terdapat keberagaman perilaku dimana ruang lingkup penelahaan BAKN begitu luas bahkan terdapat 1196 LHP, tugas penelahaan tidak sebanding dengan jumlah anggota BAKN 10 anggota. Tidak heran pada ruang lingkup perubahan perilaku dalam kebijakan ini masih belum tercapai khususnya dalam menciptakan akuntabiltias keuangan negara.
\end{abstract}

Kata Kunci: Karakteristik Kebijakan, Keuangan Negara, Badan Akuntabilitas Keuangan Negara.

\section{Abstract}

This study examines the characteristics of the problems faced by the DPR RI's State Financial Accountability Board, which has become an obstacle for BAKN in implementing policies related to state financial accountability. The research method in this study uses a qualitative approach using descriptive methods that describe the characteristics of the problem in policy implementation. The theory used is the theory of implementation proposed by Mazmanian and Sabatier. The research findings show that from the characteristics of the problem, it is known that the implementation of the MD3 policy by BAKN still has technical difficulties, including the rules including BAKN's duties only as a review. In addition, there is a diversity of behavior where the scope of BAKN review is so wide that there are even 1196 LHPs, the review task is not proportional to the number of BAKN members 10 members. It is not surprising that the scope of behavior change in this policy has not yet been achieved, especially in creating accountability for state finances.

Keywords: Policy Characteristics, State Finance, State Financial Accountability Agency. 


\section{A. PENDAHULUAN}

Gelombang pertama reformasi dalam manajemen keuangan pemerintah pada akhir 1980-an dan awal 1990-an telah berfokus pada peningkatan administrasi keuangan pemerintah dan mempromosikan transparansi dan efisiensi yang lebih besar dalam manajemen keuangan publik (Dorotinsky, 2002). Selama tahun 1990-an, sebagian besar negara Amerika Latin telah melakukan upaya signifikan untuk meningkatkan manajemen keuangan publik dan sistem informasi mereka (Dorotinsky, 2002). Namun masih terdapat kekurangan perhatian yang diberikan pada kebutuhan simultan untuk memperkuat mekanisme akuntabilitas, pengendalian dan integritas dalam manajemen anggaran. Pengalaman Peru pada 1990-an dengan jelas menunjukkan batas pengambilan keputusan yang cepat dan konsekuensinya perlu memperkuat mekanisme akuntabilitas.

Upaya memperkuat akuntabilitas eksekutif juga masih terus diupayakan negaranegara berkembang khususnya di Asia Tenggara, hasil penelitian Wiliam (dalam Ehigiamusoe, dkk, 2013) menjelaskan bahwa Indonesia dan Filipina adalah negara demokrasi baru dimana badan legislatif dibentuk melalui pemilihan yang kompetitif dalam rangka mendorong akuntabiltias eksekutif. Malaysia merupakan kasus paradigmatik otoriterisme elektoral dimana kebebasan sipil terpotong, sementara pemilihan legislatif meskipun kompetitif, namun diduga dimanipulasi dalam berbagai cara. Kamboja dan Singapura juga dapat dipahami sebagai rezim otoriter yang beroperasi meskipun daya saing mereka masih jauh berkurang. Berdasarkan hal tersebut jelas bahwa terdapat dinamika akuntabilitas publik disetiap negara yang tentunya berkaitan dengan karakteristik kondisi sistem dari setiap negara.

Sistem pemerintahan presidensial yang dipraktekkan di Indonesia membuat ketentuan untuk pemisahan kekuasaan, membagi kekuasaan dan tugas yang berbeda ke tiga tangan pemerintahan yaitu eksekutif, legislatif dan yudikatif. Pada dasarnya, legislatif membuat undang-undang yang eksekutif wajib melaksanakan. Adapun lembaga yudikatif berkaitan dengan peradilan dipanggil dalam penentuan hak-hak sipil dan kewajiban untuk menafsirkan hukum. Sistem pemerintahan presidensial memahami bahwa kekuasaan dapat disalahgunakan dan karena itu memperkenalkan sistem check and balance di antara ketiga lengan pemerintahan. Legislatif memiliki kekuatan untuk mengawasi pelaksanaan dan administrasi hukum oleh eksekutif. Eksekutif memegang kekuasaan investigasi, paksaan dan implementasi hukum dan juga dapat menggunakan kekuatan ini untuk memanggil legislatif dan yudikatif 
untuk melihat pertanggungjawaban secara hukum (Onyekpere, dalam Ehigiamusoe, dkk, 2013)).

Menurut Stair-Hall (2011), proses anggaran mencakup banyak kegiatan pengawasan yang dilakukan, hal ini karena proses alokasi berlangsung tahunan, Legilatif harus menghubungkan nilai keseluruhan suatu program dengan program lain yang bersaing untuk pendanaan dari sumber daya negara yang terbatas. Hingga taraf tertentu, legislatif menentukan tingkat pendanaan relatif untuk program berdasarkan informasi yang mereka terima dengan mempertanyakan administrator eksekutif selama dengar pendapat anggaran. Pengawasan sebagai hasil dari prinsip ini melayani sejumlah tujuan seperti; (1) Peningkatan dalam efisiensi, ekonomi dan efektivitas operasi pemerintah; (2) Evaluasi program dan kinerja; (3) Deteksi dan pencegahan administrasi yang buruk, pemborosan, penyalahgunaan, perilaku sewenang-wenang dan berubah-ubah, atau perilaku ilegal dan tidak konstitusional; (4) Perlindungan kebebasan sipil dan hak-hak konstitusional; (5) Memberitahu masyarakat umum dan memastikan bahwa kebijakan eksekutif mencerminkan kepentingan publik; (6) Mengumpulkan informasi untuk mengembangkan proposal legislatif baru atau untuk mengubah undang-undang yang ada; (7) Memastikan kepatuhan administratif dengan maksud legislatif; dan (8) Pencegahan perambahan eksekutif pada otoritas legislatif dan hak prerogative.

Stapenhurst (2012) menyampaikan bahwa legislatif adalah ruang mesin dan dimana sistem biasanya kurang berkembang, peran anggaran legislatif cenderung lemah dan tidak konstruktif. Pelizzo dan Stapenhurst (2008) menegaskan bahwa komite khusus telah muncul sebagai alat mendasar untuk pengawasan secara umum dan untuk proses anggaran dan pembelanjaan uang publik pada khususnya. Di banyak parlemen, Komite Akuntablitas Publik (KAP) berfungsi sebagai komite audit parlemen, menjadikannya lembaga inti dari bagaimana menciptakan akuntabilitas keuangan publik. Jelas bahwa pembentukan KAP sebagai alat kelengkapan parlemen menjadi penting untuk dibentuk.

Pandangan Anderson (2008) mencatat bahwa badan pengawasan yang efektif paling sering adalah mereka yang memiliki staf pendukung, mitra yang berguna, dan sekutu dari birokrasi dan masyarakat sipil. Badan-badan legislatif dan komite-komite mereka sering dibantu dalam fungsi pengawasan mereka oleh lembaga akuntabilitas ekstra-parlementer, seperti lembaga audit tertinggi dan ombudsman. Kantor akuntabilitas keuangan parlementer juga dapat memberikan keahlian dan dukungan independen kepada parlemen. Anderson (2008), menekankan nilai potensial dari unit anggaran analitik independen dalam 
menempatkan legislatif pada posisi yang lebih setara dengan eksekutif dan dalam meningkatkan transparansi, kredibilitas, dan akuntabilitas keseluruhan proses anggaran dan unit-unit tersebut harus non-partisan, independen dan obyektif dimana hal ini dalam rangka menciptakan keberhasilan dan memenuhi fungsi inti mereka.

Upaya-upaya dalam menciptakan akuntabilitas keuangan negara pada dasarnya terus dilakukan oleh berbagai lembaga parlemen yang salah satunya dilakukan parlemen Indonesia melalui Dewan Perwakilan Rakyat (DPR). DPR adalah satu lembaga negara dalam sistem ketatanegaraan Indonesia yang merupakan lembaga perwakilan rakyat. DPR terdiri atas anggota partai politik peserta pemilihan umum yang dipilih melalui pemilihan umum serentak. Pada konteks pengawasan, DPR memiliki fungsi pengawasan melalui pengawasan atas pelaksanaan Undang-Undang dan APBN.

Pengawasan DPR terhadap keuangan negara dimulai dari tahap penyusunan anggaran sesuai dengan Pasal 23 Undang-Undang Dasar Negara Republik Indonesia Tahun 1945 serta Pasal 15 Undang-Undang Nomor 17 Tahun 2003 tentang Keuangan Negara. Tetapi pengawasan terhadap akuntabilitas dan tanggungjawab keuangan negara tersebut dilaksanakan oleh DPR setelah Badan Pemeriksa Keuangan Republik Indonesia (BPK) menyampaikan laporan hasil pemeriksaan keuangan negara kepada DPR sesuai dengan Pasal 17 Undang-Undang Nomor 15 Tahun 2006 tentang Badan Pemeriksa Keuangan.

Upaya dalam rangka meningkatkan fungsi pengawasan DPR terhadap pertanggungjawaban keuangan negara, maka berdasarkan ketentuan Undang-Undang Nomor 27 Tahun 2009 tentang Majelis Permusyawaratan Rakyat, Dewan Perwakilan Rakyat, Dewan Perwakilan Daerah, dan Dewan Perwakilan Rakyat Daerah (yang lebih dikenal sebagai Undang-Undang MD3), khususnya pada Pasal 110, ditentukan bahwa Badan Akuntabilitas Keuangan Negara yang selanjutnya disingkat BAKN, dibentuk oleh DPR RI dan merupakan alat kelengkapan DPR-RI yang bersifat tetap.

Pengawasan DPR terhadap keuangan negara dimulai dari tahap penyusunan anggaran sesuai dengan Pasal 23 Undang-Undang Dasar Negara Republik Indonesia Tahun 1945 serta Pasal 15 Undang-Undang Nomor 17 Tahun 2003 tentang Keuangan Negara. Tetapi pengawasan terhadap akuntabilitas dan tanggungjawab keuangan negara tersebut dilaksanakan oleh DPR setelah Badan Pemeriksa Keuangan Republik Indonesia (BPK) menyampaikan laporan hasil pemeriksaan keuangan negara kepada DPR sesuai dengan Pasal 17 Undang-Undang Nomor 15 Tahun 2006 tentang Badan Pemeriksa Keuangan. 
Upaya dalam rangka meningkatkan fungsi pengawasan DPR terhadap pertanggungjawaban keuangan negara, maka berdasarkan ketentuan Undang-Undang Nomor 27 Tahun 2009 tentang Majelis Permusyawaratan Rakyat, Dewan Perwakilan Rakyat, Dewan Perwakilan Daerah, dan Dewan Perwakilan Rakyat Daerah (yang lebih dikenal sebagai Undang-Undang MD3), khususnya pada Pasal 110, ditentukan bahwa Badan Akuntabilitas Keuangan Negara yang selanjutnya disingkat BAKN, dibentuk oleh DPR RI dan merupakan alat kelengkapan DPR-RI yang bersifat tetap.

Dalam Menjalankan fungsi, tugas dan wewenangnya BAKN tidak luput dari berbagai permasalahan yang ada. Adapun persoalan itu berkaitan dengan apa yang dikenal dengan dengan tractability of the problem, ability of the statute to favorably structure the implementation process dan non-statutory variables affecting implementation. Dalam penelitian ini penulis akan mencoba menjelaskan tentang karakteristik permasalahan dalam implementasi kebijakan Badan Akuntabilitas Keuangan Negara DPR RI.

\section{B. METODE}

Pendekatan yang telah digunakan dalam penelitian ini adalah deskriptif analisis dengan pendekatan kualitatif. Pendekatan kualitatif didasarkan pada perumusan gejala-gejala, informasi-informasi atau keterangan-keterangan mengenai karakteristik Masalah Badan Akuntabilitas Keuangan Negara DPR RI . Berdasarkan hal tersebut jenis penelitian yang paling tepat adalah jenis kualitatif dengan metode deskriptif analisis, dimana data dan analisis lebih berbentuk kata-kata (Cresswell, 2010).

\section{HASIL DAN PEMBAHASAN}

Kebijakan Undang-Undang Nomor 2 Tahun 2018 tentang Perubahan Kedua Atas Undang-Undang Nomor 17 Tahun 2014 tentang Majelis Permusyawaratan Rakyat, Dewan Perwakilan Rakyat, Dewan Perwakilan Daerah, dan Dewan Perwakilan Rakyat Daerah (MD3), disusun untuk meningkatkan peran, fungsi dan tanggung jawab lembaga permusyawaratan rakyat, lembaga perwakilan rakyat, lembaga perwakilan daerah, sesuai dengan amanat UUD Negara Republik Indonesia Tahun 1945.

Undang-Undang MD3 juga mengatur secara komprehensif dimana tidak membatasi pengaturan yang hanya terbatas pada materi muatan susunan dan kedudukan lembaga, tetapi juga mengatur hal-hal lain yang lebih bersifat komprehensif. Menurut amanat UndangUndang Dasar 1945 pasal 20A ayat (1) menyebutkan bahwa Dewan Perwakilan Rakyat 
memiliki fungsi legislasi, fungsi anggaran, dan fungsi pengawasan. Dalam rangka meningkatkan penguatan dan pengefektifan kelembagaan DPR RI serta mendukung tugas dan wewenang DPR RI khususnya dalam fungsi pengawasan, maka dibentuk Badan Akuntabilitas Keuangan Negara (BAKN) yang ditetapkan menjadi salah satu Alat Kelengkapan Dewan (AKD) DPR RI.

Karakteristik permasalahan yang dihadapi oleh Badan Akuntabilitas Keuangan Negara DPR RI dalam mengimplementasikan kebijakan adalah sebagai berikut:

a. Kesukaran-Kesukaran Teknis

Prinsipnya hampir semua implementasi kebijakan memiliki masalah dalam hal tingkat kesulitan teknis yang dipahami oleh para implementor. Implementor dan objek pada suatu kebijakan pada realitasnya saling berkaitan satu dengan yang lainnya. Dengan begitu, berhasil atau tidaknya suatu implementasi kebijakan tentunya ditentukan pada tingkat kesulitan teknis masalah yang terjadi di lapangan, pada sisi ini Mazmanian, Daniel \& Sabatier (1983) sebagai: "The achievement of a program goal is contingent upon a number of technical prerequisites, including an ability to develop relatively inexpensive performance indicators and an understanding of the principal causal linkages affecting the problem".

Berdasarkan pendapat tersebut dapat diketahui bahwa pencapaian tujuan program bergantung pada sejumlah prasyarat teknis, termasuk kemampuan untuk mengembangkan indikator kinerja yang relatif mudah dan pemahaman tentang hubungan kausal utama yang mempengaruhi masalah. Sisi tersebut di satu pihak terdapat beberapa masalah sosial secara teknis mudah dipecahkan, di pihak lain terdapat masalah-masalah sosial yang relatif sulit dipecahkan. Oleh karena itu, sifat masalah teknis itu sendiri akan mempengaruhi mudah tidaknya suatu program akuntabilitas dapat dilaksanakan.

Berdasarkan berbagai temuan penelitian dapat diketahui bahwa pada dasarnya teknis BAKN berkaitan dengan tugas BAKN terkait: (1) melakukan penelaahan terhadap temuan hasil pemeriksaan BPK yang disampaikan kepada DPR; (2) menyampaikan hasil penelaahan kepada komisi; (3) menindaklanjuti hasil pembahasan komisi terhadap temuan hasil pemeriksaan BPK atas permintaan komisi; dan (4) memberikan masukan kepada BPK dalam hal rencana kerja pemeriksaan tahunan, hambatan pemeriksaan, serta penyajian dan kualitas laporan. Adapun hasil penelitian menunjukan bahwa terdapat beberapa masalah teknis dalam oeprasionalisasi seperti menciptakan penguatan akuntabiltias pada aspek-aspek yang strategis seperti persenjataan dan ruang lingkup pusat pemerintah dimana hal-hal ini memiliki aspek politis yang tentunya sulit untuk telaah karena masalah keamaanan negara dan kepentingan 
politik. Selain itu terkait dengan telaahan yang disampaikan BAKN ke komisi sering kurang terpantau tindaklanjutnya. Selain itu BAKN belum pernah mendapat permintaan komisi untuk menindaklanjuti hasil temuan BPK RI terkait mitra komisi. Namun hai inii tidak mengganggu kinerja BAKN secara keseluruhan, mengingat tugas utama BAKN melakukan telaahan baik regular dan tematik tetap berjalan.

b. Keragaman Perilaku Kelompok Sasaran

Mazmanian, Daniel A dan Paul A. Sabatier (1983) menjelaskan bahwa "The more diverse the behavior being regulated or the service being provided, the more difficult it become to frame clear regulations and thus the greater discretion which must be given to field level implementors". Pada penjelasan tersebut dapat diketahui bahwa semakin beragam perilaku yang diatur atau layanan yang diberikan, semakin sulit untuk membingkai peraturan yang jelas dan dengan demikian semakin besar keleluasaan yang harus diberikan kepada pelaksana tingkat lapangan.

Pada dasarnya keragaman perilaku kelompok sasaran dalam penelitian ini terbagi dua, yaitu perilaku dalam internal anggota BAKN yang kompleks dari berbagai segi, dan prilaku eksternal dalam hal ini BPK serta lembaga yang diaudit oleh BPK. Keberagaman di sisi lain adalah nilai yang dapat membangun perspektif akuntabilitas lebih luas, namun keberagaman ini dapat menjadi multi perspektif dan sulit diterjemahkan bahkan pada suatu pembuatan keputusan rapat kerja ataupun keputusan dalam menyusun formulasi rekomendasi. Untuk lebih jelasnya berikut merupakan gambar yang menerangkan keberagaman perilaku dalam implementasi kebijakan MD3 terkait BAKN: 


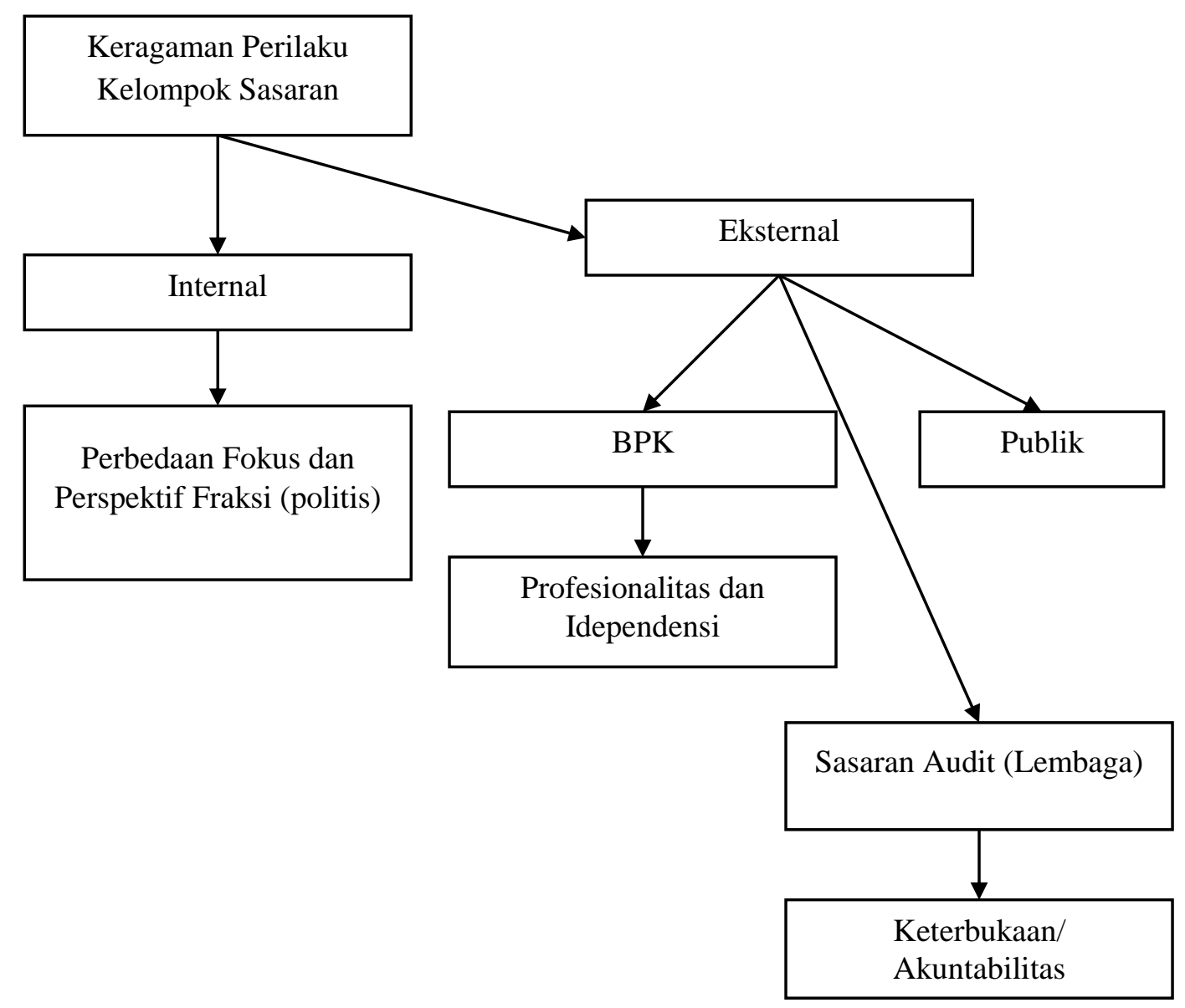

\section{Gambar 1 Keberagaman Perilaku dalam Implementasi BAKN}

Berdasarkan gambar di atas dapat diketahui bahwa untuk memastikan bahwa pengawasan akuntabilitas keuangan berjalan dengan optimal, maka BAKN tidak hanya melakukan penelaahan atau tindak lanjut pada satu pihak saja melainkan dengan berbagai pihak yang dibutuhkan, bahkan dalam satu lembaga atau badan tidak hanya menggali informasi dari satu orang saja melainkan beberapa orang terkait, untuk memastikan bahwa informasi yang didapatkan memenuhi syarat kredibel dan dapat dipercaya.

Gambar 1 menjelaskan bahwa terdapat kelompok sasaran yang memiliki berbagai perilaku, misalnya kelompok sasaran pertama yaitu internal BAKN. Hasil observasi menunjukan bahwa terdapat perbedaan perilaku khususnya pada sisi fokus dan perspektif politis anggota yang mewakili setiap fraksi. Peneliti menemukan bahwa perilaku ini lebih dekat pada politis dimana ini berkaitan dengan tingkat kepentingan fraksi pada suatu akuntabiltias. Adapun secara umum peneliti menemukan bahwa BAKN belum memiliki komitmen secara kuat untuk melakukan pengawasan keuangan negara. Idelanya secara kelembagaan, bentuk komitmen BAKN disampaikan kepada publik.

Kelompok sasaran kedua yaitu BPK, temuan menunjukan BPK merupakan mitra yang sangat strategis dalam rangka mendukung tugas BAKN. BPK memiliki sumber daya dan 
hasil kerja yang dapat menggambarkan sejauhmana akuntabiltias yang dilakukan berbagai lembaga. Pada sisi ini tingkat perilaku merujuk pada profesionalitas dan idependensi terkait hasil audit yang seusai dengan realitas. Berdasarkan temuan, BPK secara konsisten memberikan laporan audit yang sesuai dengan standar audit, pada sisi ini secara baku akuntabilitas keuangan negara sebenarnya telah terbuka untuk ditelaah, idelanya BAKN dapat memegang peranan penelaahan yang aktif berdasarkan temuan-temuan BPK.

Kelompok sasaran ke tiga yaitu lembaga yang diaudit BPK yaitu Pemerintah Pusat, Pemerintah Daerah, Lembaga Negara lainnya, Bank Indonesia, Badan Usaha Milik Negara, Badan Layanan Umum, Badan Usaha Milik Daerah, dan lembaga atau badan lain yang mengelola keuangan negara. Pelaksanaan pemeriksaan BPK dilakukan berdasarkan undangundang tentang pemeriksaan pengelolaan dan tanggung jawab keuangan negara. Pemeriksaan BPK mencakup pemeriksaan keuangan, pemeriksaan kinerja, dan pemeriksaan dengan tujuan tertentu.

Kelompok sasaran ke empat yaitu publik, pada sisi ini peneliti menemukan masih terdapat ketimpangan informasi terhadap publik dimana publik bukan saja sulit mendapat akses informasi yang strategis, namun publik tersebut masih belum masif untuk berkonrtibusi dalam menciptakan akuntabilitas. Pada sisi ini BAKN belum memberikan aspek sosialisasi yang jelas terkait posisi BAKN di mata publik, bahkan berdasarkan obervasi tidak semua tahu terkait adanya kelengkapan dewan BAKN.

Berdasarkan hasil penelitian dapat disimpulkan bahwa keragaman perilaku kelompok sasaran yang itu terbagi menjadi empat, yaitu keompok internal yaitu BAKN, kelompok eksternal yaitu BPK, Lembaga/Badan target pemeriksaan dan publik. Pada sisi ini jelas bahwa implementasi kebijakan MD3 terkait BAKN memiliki aspek yang multi sektor dimana ini menjadikan implementasi berjenjang dan membutuhkan waktu lama. Pada sisi ini keragaman perilaku berimplikasi pada tidak mudahnya BAKN dalam menelaah setiap laoran keuangan lembaga.

c. Prosentase Kelompok Sasaran Sebanding Jumlah Penduduk

Mazmanian, Daniel \& Sabatier (1983:23-24), menjelaskan bahwa: "In general, the smaller and more definable (capable of being isolated) the target group whose behavior needs to be changed the more likely the mobilization of political support in favor of the program and thus the more probable the achievement of statutory objectives".

Dari pendapat tersebut dapat diketahui bahwa secara umum dapat dikatakan bahwa semakin kecil dan semakin jelas populasi kelompok yang perilakunya akan diubah, maka 
semakin besar pula peluang untuk memobilisasikan dukungan politik terhadap program atau kebijakan, dengan demikian akan lebih terbuka peluang bagi pencapaian tujuan kebijakan. Hasil penelitian menunjukan bahwa dalam implementasi kebijakan MD3 oleh BAKN bergitu kompleks dalam rangka sasaran penelahaan laporan hasil pemeriksaan. Sebagaimana fokus dalam penelitian ini padan penelahaan 2018-2019, objek telaahan BAKN dalam LKPP tahunan 2018 terbagi menjadi dua semester yaitu:

Tabel 1 Jumlah LHP, Temuan Pemeriksaan, dan Rekomendasi BPK Semester I dan II Tahun 2018

\begin{tabular}{|c|c|c|c|c|}
\hline No & $\begin{array}{c}\text { Pemerintah/Jenis } \\
\text { Pemeriksaaan }\end{array}$ & $\begin{array}{c}\text { Jumlah } \\
\text { LHP }\end{array}$ & $\begin{array}{r}\text { Jumlah } \\
\text { Temuan } \\
\end{array}$ & $\begin{array}{c}\text { Jumlah } \\
\text { Rekomendasi }\end{array}$ \\
\hline \multicolumn{5}{|c|}{ Semester I } \\
\hline 1 & Pemerintah Pusat & 120 & 1.439 & 3.637 \\
\hline 2 & Pemerintah Daerah & 542 & 7.913 & 22.114 \\
\hline 3 & BUMN dan Badan lainnya & 38 & 456 & 1.120 \\
\hline \multicolumn{2}{|c|}{ Total } & 700 & 9.808 & 26.871 \\
\hline \multicolumn{5}{|c|}{ Semester II } \\
\hline 1 & Pemerintah Pusat & 89 & 961 & 2.317 \\
\hline 2 & Pemerintah Daerah & 369 & 2.913 & 8.366 \\
\hline 3 & BUMN dan Badan lainnya & 38 & 502 & 1.326 \\
\hline \multicolumn{2}{|c|}{ Total } & 496 & 4.379 & 12.009 \\
\hline \multicolumn{2}{|c|}{ Total Semseter I dan II } & 1196 & 14.187 & 38.880 \\
\hline
\end{tabular}

Sumber: IHPS I dan IHPS II, 2018.

Berdasarkan tabel tersebut dapat diketahui bahwa total LHP dalam semester I dan II mencapai 1.196, jumlah temuan mencapai 14.187 dan jumlah rekomenasi mencapai 38.880. Berdasarkan hal tersebut jelas bahwa kelompok sasaran penelaahan begitu besar dibandingkan dengan jumlah anggota BAKN yang terbatas. Tidak sebandingnya kelompok sasaran dengan kuantitas BAKN tentunya berimplikasi pada kinerja penelaahan akuntabiltias keuangan negara. Temuan persoalan ini berdampak pada masih terbuka ruang hasil pemeriksaan yang belum di telaah oleh BAKN.

Sebuah kebijakan dalam hal ini implementasi MD3 oleh BAKN akan relatif sulit dilaksanakan apabila sasarannya mencakup semua populasi kebijakan. Sebaliknya sebuah kebijakan implementasi MD3 oleh BAKN relatif mudah dilaksanakan apabila jumlah kelompok sasarannya tidak terlalu besar. Dalam artian bahwa implementasi MD3 oleh BAKN akan lebih mudah diimplementasikan ketika sasarannya hanyalah sekelompok orang tertentu atau hanya sebagian kecil dari semua populasi yang ada ketimbang kelompok sasarannya menyangkut seluruh populasi itu sendiri. Cakupan perubahan perilaku yang diharapkan dari implementasi MD3 oleh BAKN tersebut tentunya adalah berupa penignkatan akuntabiltias keuangan negara. 
Berdasarkan hasil penelitian dapat disimpulkan bahwa masih terdapat masalah terkait ketidakseimbangan prosentase kelompok sasaran (penelaahan LHP) sebanding jumlah anggota BAKN. Adapun implikasi yang terjadi yaitu terkait belum optimalnya penalahaan BAKN pada setiap LHP, jumlah temuan dan rekomendasi pada IHPS pada semester I dan semester II.

d. Ruang Lingkup Perubahan Perilaku yang Diinginkan

Mazmanian, Daniel \& Sabatier (1983) menjelaskan bahwa:The amount of behavioral modification required to archive statutory objectives is a function of the (absolute) number of people in the ultimate target groups and the amount of change required of them. The basic hypothesis is of course that the greater the amount of behavioral change the more problematic will be successful implementation.

Berdasarkan pendapat tersebut dapat diketahui bahwa jumlah modifikasi perilaku yang diperlukan untuk tujuan kebijakan adalah fungsi dari jumlah orang dalam kelompok sasaran akhir dan jumlah perubahan yang diperlukan dari mereka (absolut). Hipotesis dasar adalah semakin besar jumlah perubahan perilaku yang menunjukan keberhasilan dalam pelaksanaan. Adapun lebih lanjut diketahui bahwa cakupan perubahan perilaku yang diharapkan merupakan sebuah program yang bertujuan memberikan pengetahuan atau bersifat kognitif akan relatif mudah dilaksanakan daripada program yang bertujuan untuk mengubah sikap dan perilaku masyarakat.

Temuan menunjukan adanya BAKN belum tentu merubah perilaku-perilaku lembaga dalam menciptakan akuntabilitas keuangan. Misalnya ketidakpatuhan terjadi pada IHPS semeter I tahun 2019, diketahui bahwa permasalahan ketidakpatuhan sebanyak 7.636 permasalahan, di antaranya sebanyak 4.838 (63\%) dengan nilai sebesar Rp9,68 triliun merupakan permasalahan ketidakpatuhan yang dapat mengakibatkan:

1. Kerugian sebanyak 3.162 (66\%) permasalahan sebesar $\operatorname{Rp} 2,47$ triliun.

2. Potensi kerugian sebanyak 502 (10\%) permasalahan sebesar Rp 1,31 triliun.

3. Kekurangan penerimaan sebanyak 1.174 (24\%) permasalahan sebesar Rp 5,90 triliun. Selain itu, terdapat 2.798 (37\%) permasalahan ketidakpatuhan yang mengakibatkan penyimpangan administrasi. Dari 93 permasalahan ketidakhematan, ketidakefisienan, dan ketidakefektifan sebesar Rp 676,81 miliar, terdapat 39 (42\%) permasalahan ketidakhematan sebesar Rp 574,44 miliar, 2 (2\%) permasalahan ketidakefisienan sebesar Rp 33,51 miliar, dan $52(56 \%)$ permasalahan ketidakefektifan sebesar Rp68,86 miliar. Terhadap permasalahan ketidakpatuhan yang dapat mengakibatkan kerugian, potensi kerugian dan kekurangan 
penerimaan, pada saat pemeriksaan entitas yang diperiksa telah menindaklanjuti dengan menyerahkan aset atau menyetor ke kas negara/daerah/perusahaan sebesar Rp 949,10 miliar $(9 \%)$.

Berdasarkan hasil penelitian dapat diketahui bahwa implementasi MD3 oleh BAKN nyatanya tidak serta merta terdapat perubahan perilaku yang masif terhadap akuntabiltias keuangan. Bahkan ketidakpatuhan tersebut berimplikasi pada penyimpangan administrasi termasuk didalamnya ketidakhematan, ketidakefisienan, dan ketidakefektifan.

\section{KESIMPULAN}

Dilihat dari karaktersitik masalah diketahui bahwa implementasi kebijakan MD3 oleh BAKN masih memiliki kesukaran terknis termasuk aturan-aturan termasuk tugas BAKN hanya sebagai penelaahan. Selain itu terdapat keberagaman perilaku dimana ruang lingkup penelahaan BAKN begitu luas bahkan terdapat 1196 LHP, tugas penelahaan tidak sebanding dengan jumlah anggota BAKN 10 anggota. Tidak heran pada ruang lingkup perubahan perilaku dalam kebijakan ini masih belum tercapai khususnya dalam menciptakan akuntabiltias keuangan negara.

\section{DAFTAR PUSTAKA}

Abidin, S. Z. (2004). Kebijakan Publik. Jakarta: Yayasan Pancur Siwah.

Akbar, B., \& Djazuli, A. (2015). Audit Keuangan dan Kesejahteraan Rakyat Studi Pada Kabupaten Badung, Tabanan dan Kota Denpasar Tahun 2013. Jurnal Tata Kelola dan Akuntabilitas Keuangan Negara, 1(1), 1-19.

Anderson, B. (2009). The Changing Role of Parliament in the Budget Process. OECD Journal on Budgeting, 9(1), 1-11.

Anderson, J. E. (2014). Public Policymaking. Cengage Learning.

Bardach, E. (1977). The Implementation Game. Mit Press.

Barrett, S. M. (1981). Reconstructing the Field of Analysis. Policy and Action: Essays on the Implementation of Public Policy. SM Barrett and C. Fudge.

Brinkerhoff, D. W., \& Crosby, B. (2002). Managing policy reform: Concepts and tools for decision-makers in developing and transitioning countries. Kumarian Press.

Cairney, P. (2019). Understanding Public Policy. Red Globe Press.

Creswell, J. W. (2010). Research Design Pendekatan Kualitatif, Kuantitatif, dan Mixed. Yogyakarta: Pustaka Pelajar.

Dorotinsky, W. (2002). Reforma de la gestión financiera en América Latina: Una perspectiva institucional. Revista del CLAD Reforma y Democracia, (23). 
Dye, T. R., \& Dye, T. R. (1992). Understanding Public Policy. Englewood Cliffs, NJ: Prentice Hall.

Ehigiamusoe, U. K., \& Umar, A. (2013). Legislative Oversights and Budget Performance in Nigeria: Issues and Policy Options. IOSR Journal of Economics and finance, 1(5), 112.

Fox, W., \& Meyer, I. H. (1995). Public Administration Dictionary. Juta and Company Ltd.

Giacchino, S., \& Kakabadse, A. (2003). Successful Policy Implementation: The Route to Building Self-Confident Government. International Review of Administrative Sciences, 69(2), 139-160.

Hargrove, E. C. (1975). The Missing Link: The Study of the Implementation of Social Policy (Vol. 797, No. 1). Urban Inst Pr.

Hoek, F., Van Montfort, C., \& Vermeer, C. (2006). Enhancing Public Accountability in the Netherlands. OECD Journal on Budgeting, 5(2), 69-86.

Jobes. (1982). Decision Making: Approaches and Analysis. Manchester: Manchester Press

Khan, A. R. (2016). Policy implementation: Some Aspects and Issues. Journal of Community Positive Practices, (3), 3-12.

Lester, J. P., Bowman, A. O. M., Goggin, M. L., \& O'Toole Jr, L. J. (1987). Public Policy Implementation: Evolution of the Field and Agenda for Future Research. Review of Policy Research, 7(1), 200-216.

Mazmanian, D. A., \& Sabatier, P. A. (1983). Implementation and Public Policy. Scott Foresman.

OECD. (2002). OECD best practices for budget transparency. OECD.

Rahmatika, D. N. (2014). The Impact of Internal Audit Function Effectiveness on Quality of Financial Reporting and its Implications on Good Government Governance Research on Local Government Indonesia. Research Journal of Finance and Accounting, 5(18), 64-75.

Sabatier, P. A. (1986). Top-down and bottom-up approaches to implementation research: a critical analysis and suggested synthesis. Journal of Public Policy, 21-48.

Santiso, C., \& Belgrano, A. G. (2004). Legislative Budget Oversight and Public Finance Accountability in Presidential Systems: Governance of the Budget in Peru, paper prepared for the XVI Regional Seminar on Fiscal Policy of ECLAC (UN Economic Commission for Latin America and the Caribbean), Santiago de Chile, 26-29 January.

Stair-Hall, G. (2011). Legislative Oversight: A Guidebook for Ohio Legislators. Ohio Legislative Service Commission.

Sukmadilaga, C., Pratama, A., \& Mulyani, S. (2015). Good governance implementation in public sector: Exploratory analysis of government financial statements disclosures across ASEAN Countries. Procedia-Social and Behavioral Sciences, 211, 513-518.

Undang-Undang Dasar Negara Republik Indonesia Tahun 1945 serta Pasal 15 UndangUndang Nomor 17 Tahun 2003 tentang Keuangan Negara

Undang-Undang Nomor 15 Tahun 2006 tentang Badan Pemeriksa Keuangan. 
Undang-Undang Nomor 27 Tahun 2009 tentang Majelis Permusyawaratan Rakyat, Dewan Perwakilan Rakyat, Dewan Perwakilan Daerah, dan Dewan Perwakilan Rakyat Daerah

William, N. D. (2003). Pengantar Analisis Kebijakan Publik. Yogyakarta: Gadjah Mada University Press. 